\title{
Sovereign Default Disputes in Investment Treaty Arbitration: Jurisdictional Considerations and Policy Implications
}

Josef Ostřanský*

DOI: $10.21827 / 5 a 86 a 874244 c c$

\section{Keywords}

SOVEREIGN DEFAUlt; INTERNATIONAL INVESTMENT LAW; INVESTMENT ARBITRATION; INTERNATIONAL FINANCIAL LAW; SOVEREIGN FINANCING

\begin{abstract}
In the aftermath of Argentina's 2001 economic crisis, creditors not participating in the country sovereign debt restructuring insisted on full payment. The triplet of investment arbitration decisions upheld jurisdiction over the mass claims presented by the holdout creditors. ${ }^{1}$ Two cases were, however, accompanied by forceful dissents. Subsequently, opinions diverged into two camps on the legal appropriateness and policy desirability of using investment arbitration for solving sovereign default disputes: the first camp supporting the majority's view, and the second siding with the dissenting arbitrators. This article analyses the two approaches as far as jurisdictional requirements for hearing the sovereign bond disputes are concerned as well as potential policy consequences of the use of investment arbitration for these types of disputes. The article assumes a critical position towards the reasoning of the three awards, mostly due to the misconceived apprehension of the requirement of territoriality. In the policy part, the article argues that even if one assumes that enhancement of the creditor's rights is desirable (something which is debatable), investment arbitration does not seem to bring advantages towards that goal. First, the argument of better enforcement of arbitral awards seems to be more apparent than real. Second, as Bilateral Investment Treaties base their protection on nationality, this fact creates unjustifiable preference towards certain creditors and increases unpredictability. This uncertainty upsets the original contractual bargain agreed on the issuance of bonds and has negative repercussions in financial markets. The ad hoc nature of investment arbitration only furnishes the uncertainty. Lastly, investment arbitration is a tool for correcting past grievances. Tools for dealing with orderly sovereign defaults should focus on the preventive aspects of sovereign defaults. As a robust multilateral treaty system dealing with sovereign defaults is currently politically unfeasible, a better solution is to reinforce the current system of contractual protections such as collective action clauses or exit consents. Rather than attempting to expand the role of arbitration, resolving sovereign debt issues should be left to actors in financial
\end{abstract}

PhD Candidate at the Graduate Institute of International and Development Studies, Geneva; Research Assistant at the Geneva Centre for International Dispute Settlement (CIDS).

1 Abaclat and others $v$ Argentine Republic, ICSID Case No ARB/07/5, Decision on jurisdiction and admissibility, 4 August 2011 (Abaclat); other two cases dealing with the same factual matrix are Ambiente Ufficio SpA and others $v$ Argentine Republic, ICSID Case No ARB/08/9, Decision on Jurisdiction and Admissibility, 8 February 2013 (Ambiente); and Giovanni Alemanni and others v Argentine Republic, ICSID Case No ARB/07/8, Decision on Jurisdiction and Admissibility, 17 November 2014 (Alemanni). 
markets (lenders and borrowers). Financial markets have always proved capable of dealing with sovereign defaults.

\section{Introduction}

Sovereign borrowing for financing fundamental State functions has been present for many centuries. When States have refused to pay their debts traditionally owed to other sovereign States, they have done so either due to lack of funds or simply because of their unwillingness. International solutions to sovereign defaults utilised throughout history have varied significantly, also due to the fact that the nature of international economy and financial markets has been in a state of constant evolution. Still, international law on sovereign defaults remains an underdeveloped area. ${ }^{2}$ Under the current state of affairs there is nothing like an international law of insolvency, as the process remains political to a large extent. ${ }^{3}$

The structure of sovereign debt has changed dramatically during the 20th century and every wave of sovereign debt crisis had different characteristics from the previous one. The current international financial market of sovereign lending is dominated by bonds. In the second half of the $20^{\text {th }}$ century, States' financing was funded mostly by loans provided by commercial banks. ${ }^{4}$ The current bond market is characterised by a distinct feature the secondary market. Bonds are issued to so-called 'underwriters' or 'intermediaries' and the security entitlements arising out of the issuance are subsequently traded in the secondary market to various customers, be they financial institutions or retail bondholders. The result of this is a high diversity of holders of sovereign bonds and a higher number of creditors dispersed across the globe.

State insolvency procedures cannot entirely mirror the procedures of bankruptcy as known in various domestic legal systems. States' assets, not to mention the State itself, cannot be entirely divided between creditors. States simply cannot be liquidated. 'Selling a State' goes against the notion of sovereign equality of States, and due to the specific nature of States' international legal personality, the procedures used for dealing with defaults on sovereign debt cannot be the same as in the domestic context. The corporate nature of a State is of a different quality than that of an enterprise. States have to fulfil many public functions that they owe to their populations and comply with other obligations under international law. Thus, the international legal regime governing sovereign defaults must find an appropriate balance between the interest of the State and its population, which in the end suffers the most from the consequences of default and the interests of creditors. The latter interests at present may vary significantly, but the major interest is nevertheless to get the agreed amount of money due.

The situation of sovereign default is usually attributed to irresponsible economic policies pursued by a State. Although this might be a major factor influencing the existence of default, the situation is hardly that simple. Financial crises may be a result of

2 Waibel, M, Sovereign Defaults Before International Courts and Tribunals (Cambridge University Press, Cambridge, 2011), 12.

3 Fox, H, The Law of State Immunity (2nd ed, Oxford University Press, Oxford, 2008), 600.

4 This is mostly with the emergence of the doctrine of restrictive immunity. Until the middle of the 20th century, sovereign debts were mere engagements of honour: Buchheit, LC, Sovereign Debt in the Light of Eternity, presented at the Graduate Institute of International Development Studies, Geneva, 7 March 2013 , <graduateinstitute.ch/files/live/sites/iheid/files/sites/cfd/shared/docs/2758917_1(Sovereign\%20Deb t\%20-\%20in\%20the\%20Light\%20of\%20Eternity\%20-\%20Draft\%20-\%207_3_13).PDF> (accessed 10 May 2015), 3. 
the general situation of the global economy, which is currently highly interdependent. Thus, the risk of contagion of economic depression is more probable and common. Furthermore, impacts of climatic conditions, such as extensive draughts, can affect the revenues States gather from crop export. Fluctuations in prices of exported raw materials may also be beyond the control of the State. The causes of a crisis are seldom purely internal. It can be said that the causes of sovereign defaults fall into two categories: mismanagement and misfortune. ${ }^{5}$

The process of finding solutions to an unsustainable debt burden involves negotiations between the State and its creditors, where various interests must be channelled into finding an agreeable solution to the problem. Notwithstanding the nature of the debt instruments in question, the solutions usually consist of, for example, reducing the amount of debt, reductions of principal, lowering the interest rate, prolongation of maturity and at times, even full repayment. The primary issue in the event of default on sovereign debt is to restructure the debt in a way that allows the debtor State to fulfil its payment obligations under workable terms and thus keep being functional as a State. As sovereign debt can be considered a perennial condition, ${ }^{6}$ the result of a State's financial creditworthiness is market access. ${ }^{7}$

In the aftermath of the Argentine financial crisis of 2001, investment treaty arbitration, and the International Centre for Settlement of Investment Disputes (ICSID) in particular, has arisen as a new forum for dissatisfied creditors, where they can pursue their claims on defaulted debts. The intersection between the international regime on sovereign defaults and the world of investment arbitration has materialised with the claims of approximately 180,000 Italian bondholders initiating arbitral proceedings against Argentina. ${ }^{8}$ The issues arising from this new encounter are important for both worlds, ie the practice of sovereign debt restructuring and international financial law on the one hand, and international investment law on the other, which have so far been evolving separately. The main questions which arise are whether the regime of international investment arbitration in its current shape is designed to and suitable for dealing with sovereign defaults, and how the fact that this forum is being used for solving this kind of disputes will affect the practice of States in the event of unsustainable external debts. These issues are not only of a technical legal nature; this encounter brings to the forefront many policy issues of international dispute settlement and international finance.

The role of international law in the regulation of sovereign lending is '[assisting] in providing external disciplines to anchor a sound and solid national monetary policy in international, enforceable disciplines and institutions less exposed to short-sighted

5 International Law Association (ILA), Sovereign Insolvency Study Group, Wood, PQC, Hunt, B and Waibel, M, REPORT: State Insolvency: Options for the Way Forward, The Hague, August 2010, at <ilahq.org/download.cfm/docid/0A7ACEAC-94A3-4B47-B9E642CF4BEA5D81> (accessed 24 April 2015), 6 (ILA, Sovereign Insolvency).

6 In a sense that, nowadays, no one expects that a State will have the money once the obligation matures, but that it will simply be able to incur further public debt to repay the older obligation.

7 Buchheit, supra nt 4,6.

8 Abaclat: To be precise, the arbitration later followed with around 60,000 claimants, after some of the bondholders tendered to the 2010 exchange offer. Subsequent cases following the majority in Abaclat on the question of jurisdiction and admissibility are Ambiente Ufficio SpA and others $v$ Argentine Republic, ICSID Case No ARB/08/9 (formerly known as Giordano Alpi and Others v Argentine Republic), Decision on Jurisdiction and Admissibility, 8 February 2013 and Dissenting Opinion of Santiago Torres Bernárdez, 2 May 2013 (Ambiente, Dissenting Opinion); Alemanni. 
national policies of repudiating debt, usually as a result of domestic politics.' International law in this area ought to provide support for economic development. Therefore, the rules governing international defaults should strike a balance between the respect for sanctity of debt and contractual obligations arising therefrom on the one hand, and the practical needs of the State as far as its population is concerned, on the other. The latter should take into account the realistic possibilities of the debtor country fulfilling its debt obligation without stalling its functioning as a State. The international investment regime should

help to rather than hinder ... restructuring; [it] should support rather than undermine efforts at getting the debtor nation back into a solid financial and monetary position; [it] should not encourage too much of 'moral hazard' by completely eliminating the risk consciously assumed ... . ${ }^{10}$

However, this can be so only on the assumption that this forum is indeed legally available to the distressed debtors. As compared to the issues highlighted in the previous paragraphs, this question is and must be answered only by reference to the law applicable to such disputes.

This article addresses the intersection between the law and practice on sovereign defaults and the international regime for foreign investment. It asks the question whether it is desirable to reinforce creditors' rights, and particularly what problems in the practice of sovereign defaults can be remedied through the use of investment arbitration. Finally, it attempts to draw policy implications this encounter can bring.

The article proceeds as follows. First, the nature of sovereign defaults on bonds will be described, and the mechanisms available and utilised to deal with them will be briefly presented. In this part, the pertinent issues, especially the problem of holdout creditors and holdout disputes, will be analysed. In the second part, one of the major legal issues arising in investment arbitration on sovereign defaults will be presented. These issues concern jurisdiction of the arbitral tribunal when faced with a sovereign debt related dispute. This part will critically analyse the triplet of decisions on jurisdiction and admissibility thus far issued against the Argentine Republic. ${ }^{11}$ The third and final part will focus on policy issues and suggestions for future developments on the subject-matter. The article will therefore attempt to build a bridge between international financial law, which has so far been the primary field in which the debate on sovereign lending has occurred, and international investment law. The main emphasis will be put on policy issues that arise out of this encounter. ${ }^{12}$

9 Wälde, T, "The Serbian Loans Case: A Precedent for Investment Treaty Protection of Foreign Debt?" in Weiler, T, ed, International Investment Law and Arbitration: Leading Cases from ICSID, NAFTA, Bilateral Treaties and Customary International Law (Cameron May, London, 2005), 383-384.

$10 \quad I d, 386$.

11 Substantive investment law and causes of action that can be invoked when applied to a sovereign default, such as expropriation, fair and equitable treatment, umbrella clause, national and most favoured nation treatment, will not addressed by the paper. For an overview of this topic see eg., Wälde, supra nt 9.

12 Sovereign lending provided by multilateral lending agencies and governments are not covered by the article as the mechanisms applied to settling their claims differ, mostly due to their international legal personality and their preferential stance in the area of international finance. 


\section{Sovereign Defaults and Disputes Arising Therefrom}

\section{II.1. Current Character of Sovereign Borrowing}

Governments fund their functioning mostly through debt. Providers of financing are of three types: 1. So-called official creditors, ie other States; 2. International development institutions, such as the International Bank for Reconstruction and Development (IBRD), the International Monetary Fund (IMF) or bilateral governmental agencies; and 3. Commercial private creditors, such as private banks, funds or retail commercial creditors. ${ }^{13}$ Two types of government debt exist. First, internal debt denominated in its own currency. A State cannot practically default on its internal debt as it can always print more of its own currency. The second type is the debt this article is focusing on, namely external debt in foreign currency. Although no generally accepted definition of sovereign default exists, we can refer to it as a situation when 'a scheduled [sovereign] debt [ie a debt incurred by governments] service is not paid beyond a grace period specified in the debt contract. ${ }^{14}$

Sovereign defaults bring along costs for governments and their population and these costs are often quite harsh. ${ }^{15}$ From the point of view of financial markets, the government in default incurs costs generally of two kinds. First, sanctions by creditors represented mainly by increased borrowing costs. Second, signalling costs which put the sovereign's creditworthiness in question and thus further increase the borrowing costs and willingness to lend by potential creditors. ${ }^{16}$ It cannot be seen in the interest of the State itself to repudiate the debt entirely or to subject creditors to an unreasonably substantial haircut, as this would have a large effect on the country's reputation and creditworthiness and would hamper its ability to access further money. Negative consequences for the State's population would follow.

Sovereign debts are characterised by the lack of effective mechanisms for enforcement as compared to those of corporate debt. ${ }^{17}$ Besides that, the presence of sovereign risk in certain types of sovereign debts is what makes such debt different from an ordinary debt between private parties. Sovereign risk materialises in three aspects: 1. Law-making power; 2. Sovereign immunity; and 3. Lack of international features of State insolvency. ${ }^{18}$ Elimination of some aspects of sovereign risk is done through various devices, most of which are of a contractual nature, for example, choice of law clauses, while other aspects remain largely un-remedied, for example, sovereign immunity from execution or the lack of bankruptcy-like features on the international level (impossibility of assets freeze, distressed debtor financing, lack of priority rules, etc).

13 Barra, M, "Remedies to Default on International Lending: Any Improvement from Bilateral Investment Treaties?", 2(1) Transnational Dispute Management (2005), at <transnational-disputemanagement.com/article.asp?key=363> (accessed 24 April 2015).

14 Hatchondo, JC, Martinez, L and Sapriza, H, "Understanding Sovereign Default" in Kolb, RW, ed, Sovereign Debt: From Safety to Default (John Wiley and Sons, Hoboken, 2011), 137.

15 Common consequences are currency collapses, radical slow-down of the economy, high inflation, possible collapses of banking system, inability of servicing foreign currency debt, drying up of credit, lack of foreign investments, limited access to the international financial market, non-functioning of public services and general impoverishment of the population.

16 Hatchondo et al, supra nt 14, 138-139.

17 Sturzenegger, F and Zettelmeyer, J, Debt Defaults and Lessons from a Decade of Crises (MIT Press, Cambridge, 2006), 55.

18 Barra, supra nt 13, 2. 
When a State experiences difficulties with serving its external debt, it historically employed various measures, be it rescheduling, moratorium or sometimes repudiation.

\section{II.2. Changes in the Nature of Sovereign Defaults in the Second Half of the 20th Century}

\section{II.2.1. 1980s Commercial Bank Loans Crisis and the Brady Plan}

The structure of international capital flows changed remarkably in the 1970s. Until then, sovereign debts had been mostly consisting of bonds held by thousands of holders from the major capital exporting countries. The providers of lending had been either sovereign or intergovernmental multilateral lenders. In the 1970s sovereign lending became a domain of syndicated bank loans, and the private sector started to be heavily involved. ${ }^{19}$

The 1980s crisis of sovereign debt had its origin in the practice of commercial banks lending large sums of money to developing countries, particularly in Latin America. During the 1970s, commercial banks had accumulated vast amounts of liquidity from oil rich countries, which they needed to invest. As the developed world was suffering from recession, developing countries were ideal candidates to lend the money to. Not to mention that from the borrowing countries' point of view, the loans were also very attractive as high inflation in the US helped to counter high interest rates on the commercial loans. ${ }^{20}$ By the end of 1970s, due to the 1979 oil crisis, the price of oil skyrocketed, pushing developing countries to borrow more. As prices of other raw materials plummeted, their export revenues decreased and made it difficult to service their debts. ${ }^{21}$

The main coordination channel in the restructuring of the commercial bank debt in the then series of crises in the late 1970s and during the 1980s was the process widely known as 'London Club'. The process involved the so-called 'Bank Advisory Committees' (BACs), which were ad hoc international informal associations of senior officials of the banks having the largest exposure in a particular country. ${ }^{22}$

Several re-schedulings of the commercial bank loans during the 1980s with Mexico, Argentina, Brazil, Chile and other States, had not been sufficient to solve the crisis, which originally was viewed as a crisis of liquidity and not of solvency. ${ }^{23}$ The rescheduling was only postponing a default or some other more definite solution. The final way out of the debt crisis that commenced in the early 1980s with the Mexican crisis took place at the beginning of 1990s, with help from the official sector. The IMF, as the main coordinator, lent money to the States experiencing debt-servicing difficulties, subject to policy adjustments in these countries. The IMF also had an undeniable facilitative role as an honest broker in negotiations between the private sector and the debtor countries. But the resolution of the crises took place with adoption of the 'Brady Plan', which was strongly backed by the US.

In 1989, US Treasury secretary Nicholas Brady announced a restructuring strategy that had, as a main feature, exchange of the commercial bank debt for tradable bonds, so-

19 Rieffel, L, Restructuring Sovereign Debt: The Case for Ad Hoc Machinery (Brookings Institution Press, Washington DC, 2003), 96-97. Commercial banks operating in syndicates of generally 10 to 20 banks were main providers of funds to developing countries.

20 Power, PJ, "Sovereign Debt: The Rise of the Secondary Market and its Implications for Future Restructurings", 64(6) Fordham Law Review (1996) 2701, 2707.

21 Ibid.

22 Sturzenegger and Zettelmeyer, supra nt 17, 11.

$23 \mathrm{Id}, 17$. 
called 'Brady bonds'. ${ }^{24}$ In Brady deals, creditors (represented for every debtor State by a BAC), accepted lower and safer payments where principal was collateralised by zerocoupon US Treasuries (so-called 'securitisation' or 'enhancement') ${ }^{25}$ The IMF and other official agencies provided financing for buying collateral or for buybacks. Creditors could have chosen between several types of Brady bonds. ${ }^{26}$ These deals were concluded with approximately 20 developing States experiencing debt-servicing difficulties. Last but not least, the Brady plan support was conditional upon implementation of comprehensive scheduled reforms. Since the implementation of the Brady plan, the nature of sovereign debt has switched from the syndicated bank loans to sovereign bonds as the main form of private debt flows.

\section{II.2.2. Bond Crises of the Late 1990s and Early 2000s}

The first wave of defaults on sovereign bonds occurred in 1998, following the Mexican peso crisis of 1994. The nature of these defaults was different from the crises experienced before and struck the markets as a surprise. ${ }^{27}$ The debate that was initiated then was concerned mostly with ways to increase the involvement of the private sector in restructuring, how to attain more equitable burden sharing between the official and private sector and how the official sector can avoid allegations of bailing-out private creditors via massive rescue packages. ${ }^{28}$

The foregoing historical exposé is meant to provide wider economic and political context of the crisis that is at the centre of the three Argentinian investment cases. It also was supposed to highlight the fact that the ever-changing nature of sovereign defaults makes it difficult to create a universal solution. Apart from that, it shows that flexible political and financial mechanisms are perhaps better equipped to solve such disputes than adjudicative mechanisms oriented to right past wrongs on the basis of application of law. ${ }^{29}$ As this paper is based mostly on the recent Argentinian default due to its relevance to investment arbitration, the crisis deserves a brief description.

\section{II.2.2.1. Argentine Financial Crisis}

Argentina suffered a major financial crisis at the turn of the century. In 2001 it declared a moratorium on service of its outstanding external debt. This sovereign default is considered to be the largest and the most complex in history. ${ }^{30}$ In figures, Argentina

24 Besides the bonds, the countries could have chosen other types of assets, eg., debt buybacks or equity participation in privatised State enterprises (swaps). Eg., Rieffel, supra nt 19, 150.

25 US Securities and Exchange Commission, Zeron Coupon Bonds, at <sec.gov/answers/zero.htm> (accessed 24 April 2015):

Zero coupon bonds are bonds that do not pay interest during the life of the bonds. Instead, investors buy zero coupon bonds at a deep discount from their face value, which is the amount a bond will be worth when it "matures" or comes due. When a zero coupon bond matures, the investor will receive one lump sum equal to the initial investment plus the imputed interest.

26 'Par bonds' - the same principal but lower interest; 'discount bonds' reduction of face value combined with market interest. These bonds have long maturity, usually of 30 years. Shorter-term bonds were also available - 'PDI (part due interest) bonds' - issued for exchange of past due interest without collateral in US Treasuries.

27 Up to the Mexican crisis of 1994, debt service difficulties had occurred due to current account imbalances. The Mexican crisis started in the form of imbalances in the capital account. The crisis was cured with help of a massive rescue package (USD 50 billion) provided by the US and multilateral lenders. Rieffel, supra nt 19, 192,

$28 I d, 221$.

29 Buchheit, supra nt 4, 4.

30 Waibel, supra nt 2, 15. 
defaulted on about USD 120 billion in private debt and on more than USD 30 billion of official debt. ${ }^{31}$

The causes of the crisis are ascribed partly to the external events such as the fallout of the financial crises in Russia, South East Asia and Brazil, and partly to the internal economic policies. In the beginning of the 1990s Argentina suffered from hyperinflation. During the 1990s the country experienced strong economic growth combined with heavy budget deficit and high interest rates which led to recession. Argentina started to borrow heavily and attracted investors by linking the peso to the US dollar in one-to-one fixed rate. At the turn of the century, Argentina implemented tax increases and pushed up interest rates, reducing confidence in the peso. A decrease in credit rating followed and made interests on debt too high and its service unsustainable. Adverse effects were mostly in the form of capital flight, the money being heavily withdrawn from the banking system, and a large decrease of capital inflow. Following the events the government implemented various emergency measures such as a freeze on banks, debt moratorium etc. ${ }^{32}$ The impacts on the private sector and population were enormous.

In the subsequent efforts to restructure its debt, the Argentine government moved to offer an exchange of the defaulted bonds for new instruments with modified terms. To the foreign creditors, accepting the exchange offer meant a haircut of about $75 \%$ of the originally agreed payments in principal and interest. Nevertheless, approximately $76 \%$ of the outstanding bondholders tendered in $2005 .{ }^{33}$ Concurrently with the first exchange offer Argentina adopted legislation that it would never propose any future swap with a better offer, and that also prohibited all agencies to settle, in-court or out-of-court, with the holdout creditors. ${ }^{34}$ However, a second exchange offer followed in May 2010 in which $66 \%$ of the holdout bondholders participated. Therefore, the creditor participation rate with both of the exchanges taken together reached $92.5 \%{ }^{35}$

The non-participant creditors in the Argentinian default first pursued litigation for collecting their debts in the courts of various jurisdictions, but without any significant success in enforcement of the judgments obtained. ${ }^{36}$ From 2006 onwards several ICSID

$31 \quad I d, 16$.

32 US Congress, Joint Economic Committee, Saxton, J, Argentina's Economic Crisis: Causes and Cures, June 2003 at <hacer.org/pdf/Schuler.pdf> (accessed 7 April 2015), 30; Congressional Research Service (CRS), REPORT: Hornbeck, J, The Argentine Financial Crisis: A Chronology of Events, 31 January 2002, at $<$ fpc.state.gov/documents/organization/8040.pdf> (accessed 7 April 2015).

33 Halverson Cross, K, "Arbitration as a Means of Resolving Sovereign Debt Disputes" 17(3) American Review of International Arbitration (2006) 335 (Halverson Cross 2006).

34 Ley 26.017 (Law 26.017), Argentina (2005), at <infoleg.mecon.gov.ar/infolegInternet/anexos/100000104999/103619/norma.htm> (accessed 8 March 2015); United Nations Conference on Trade and Development (UNCTAD), Sovereign Debt Restructuring and International Investment Agreements (2011) 2 IIA Issues Note 3 (UNCTAD, Sovereign Debt Restructuring).

35 Waibel, supra nt 2, 18.

36 After a judgment issued by the Second Circuit Court's Judge Griesa ruling that a pari passu clause entitled holdout creditors to the repayment at full face value, while disenabling Argentina to pay $93 \%$ of the bondholders of the restructured bonds without paying in full to the holdouts, Argentina found itself in a selective default. The discussion of the 'NML saga' is beyond the scope of this article. International reactions to the ruling were far from favourable, though. This is due to the possibility given to holdouts to attach payments on restructured debt, which can seriously undermine any future sovereign debt restructuring. For details see eg., UNCTAD, Argentina's 'vulture fund' crisis threatens profound consequences for international financial system, 24 June 2014, at $<$ unctad.org/en/pages/newsdetails.aspx?OriginalVersionID=783\&Sitemap_x0020_Taxonomy=UNCT AD\%20Home> (accessed 10 March 2015); EJIL Talk!, Desierto, D, Republic of Argentina v NML Capital Ltd: The Global Reach of Creditor Execution on Sovereign Assets and The Case for an International Treaty on Sovereign Restructuring, 22 June 2014, at <ejiltalk.org/republic-of-argentina-v-nml-capital-ltd-the-global- 
arbitrations have been initiated by the holdout creditors with the view of recovering the outstanding debt in full.

\section{II.2.3. Defaults on Commercial Bank Loans and Sovereign Bonds Compared}

The main advantage of bonds is their flexibility in comparison with bank loans. They include less restrictive covenants, have longer maturities and are easily listed and traded on stock exchanges. ${ }^{37}$ On the other hand, bonds are more difficult to restructure, as the consent of all bondholders of one issue is generally required.

Involvement of BACs in rescheduling in the 1980s and early 1990s was quite efficient and communication channels between the defaulting States and creditors had been functioning rather well. The great difference between the set of crises during 1998-2005 and the commercial bank loans crisis is that in the later crises creditors were highly heterogeneous and were not represented by banks or similar institutions. ${ }^{38}$ This is mostly due to the emergence of the secondary market where the holder of a sovereign bond can become virtually anyone. ${ }^{39}$ The diverging interests are amplified by the decreasing number of repeat players in the bond markets compared to commercial bank loans. The emergence of the secondary market brought along new players in the international financial market, so-called 'vulture funds'. These entities buy distressed debts at highly discounted prices and then attempt to collect the full payment via litigation strategy. ${ }^{40}$

This factor makes creditor coordination a burdensome exercise. Despite this fact, the restructuring of recently defaulted debts took generally less time than the rescheduling negotiations in the 1980s and 1990s of syndicated bank loans. Settlements were usually reached in months, with the exception of Argentina. Sturzenegger and Zettelmeyer ascribe this to a more assertive approach of defaulting States in presenting creditors with take-it-or-leave-it exchange offers. This approach puts pressure on bondholders and as an alternative it provides them only an uncertain and lengthy holdout litigation strategy or sale of bonds at distressed prices. ${ }^{41}$ This approach used by States has generally been quite

reach-of-creditor-execution-on-sovereign-assets-and-the-case-for-an-international-treaty-on-sovereignrestructuring/> (accessed 7 April 2015); United States Court of Appeal, EM Ltd v Republic of Argentina 695 F3d 201 (2d Cir 2012); United States Court of Appeal, NML Capital Ltd v Republic of Argentina, 473 F3d 463 (2d Cir 2007); Halverson Cross, K, "Investment Arbitration Panel Upholds Jurisdiction to Hear Mass Bondholder Claims against Argentina" 15(30) American Society of International Law Insights (Halverson Cross 2011); US Congressional Research Service, Hornbeck, J, REPORT: Argentina's Defaulted Sovereign Debt: Dealing with the "Holdouts", February 2010, at <fpc.state.gov/documents/organization/139277.pdf> (accessed 7 April 2015); Szodruch, A, "State Insolvency - Consequences and Obligations under Investment Treaties" in Hoffmann, R, and Tams, CJ, eds, The International Convention for the Settlement of Investment Disputes (ICSID): Taking Stock after 40 Years (Bade-Baden: Nomos, 2007), 146.

37 Fisch, JE and Gentile, CM, "Vultures or Vanguards?: The Role of Litigation in Sovereign Debt Restructuring" 54 Emory Law Journal (2004) 1072; Barra, supra nt 13.

38 Fisch and Gentle, supra nt 37, 1074. Several informal bondholders associations have been created in the aftermath of the Argentine crisis, eg., Global Committee of Argentine Bondholders (GCAB), at <tfargentina.it/download/GCAB-press-release120104.pdf> (accessed 7 April 2015); Task Force Argentina (TFA), at <http://www.tfargentina.it/english.php> (accessed 7 April 2015).

39 A secondary market of sovereign debt came to existence during the era of 1980s financial crisis as the banks that had provided loans to governments started to trade distressed sovereign debts to third parties in order to limit their exposure to these countries. See eg., Power, supra nt 20, 2701; Fisch and Gentile, supra nt 37, 1068.

40 Ibid.

41 Sturzenegger and Zettelmeyer, supra nt 17, 14. 
successful, even in the case of the Argentine default, where the losses suffered by the exchanges amount to $75 \%$ of the original contracted amount.

\section{II.3. Coordination Between Creditors as a Collective Action Problem - The Issue of Holdouts ${ }^{42}$}

Once a State falls into arrears with its external debt or is undergoing financial difficulties with debt servicing approaching default, creditors have basically two options. First, negotiate with the State a workout of the unsustainable debt, or second, forego a strategy of legal action to enforce their contractual rights in court or in arbitration. ${ }^{43}$

As mentioned above, one of the obstacles in achieving orderly and fair restructuring is to maintain cooperation between creditors, and in the era of bonds dispersed between various holders this problem is enhanced. Against the background of the current sovereign bond market, this collective action problem materialises in the phenomenon of holdouts. Holdout is a tendency of minority creditors to free ride at the expense of majority creditors. Holdout creditors pursue their contractual rights before various fora to achieve a full repayment. When a State is unable to repay its debt in full it cannot be reasonably insisted that full repayment is the only solution to the problem. A majority of creditors are usually aware of these limitations and are willing to undergo some degree of a haircut.

The holdout problem therefore arises from diverging interests of creditors and out of their assessments of success in obtaining full repayment of the debt obligation. 'If creditors know that a 'holdout' can obtain full repayment conditional on a previous debt restructuring, everyone will want to be that holdout, and no one will want to restructure'. ${ }^{4}$ Thus, one of the major challenges in negotiating sovereign debt restructuring is to channel different interests of the parties involved in order to attain a mutually agreeable solution. Due to the number of creditors involved in the current sovereign bond market and the nature of bonds, a great deal of organization is necessary in order to coordinate their collective interests. ${ }^{45}$

Until the middle of the 20th century, without the creditor's national State interference in the form of diplomatic protection, creditors' rights were virtually impossible to enforce. ${ }^{46}$ In the 1980 s financial crisis, commercial banks providing loans to the defaulting countries were rather few in numbers, thus the issue of holdouts did not come up with a great intensity. When it happened, the tools employed were usually combination of official pressure, debt buybacks, buyouts, but also full repayment in cases of small amounts. ${ }^{47}$ The dissenting banks were often small commercial banks that had

42 Apart from the collective action problem, there are other issues with sovereign indebtedness, which cannot be treated here. These issues are, for instance, lack of stay of enforcement against a distressed debtor and lack of priority rules, no formal rules for emergency financing and coordination between workouts of the domestic and foreign debt.

43 Schlemmer, EC, "The Enforcement of Sovereign Debt" in Giovanoli, M and Devos, D, eds, International Monetary and Financial Law: The Global Crisis (Oxford Univerity Press, Oxford, 2010), 425.

44 Sturzenegger and Zettelmeyer, supra nt 17, 64.

45 Barra, supra nt 13, 3; Fisch and Gentile, supra nt 37.

46 For the landmark case on sovereign debt before the PCIJ see eg., Permament Court of International Justice (PCIJ), Case Concerning Various Serbian Loans Issued in France (France v Serbia), 12 July 1929, Series A No 20; for the statutes which restrict the sovereign immunity see eg., Sections 1330 and 1332(a), Federal Sovereign Immunities Act 1976, United States, (1976), Public Law 94-583, 28 USC Chapter 33, State Immunity Act 1978, United Kingdom (1978).

47 Sturzenegger and Zettelmeyer, supra nt 17, 11; Fisch and Gentile, supra nt 37, 1065. 
not had any long-term interest in providing further services on a medium or large-scale basis to the indebted States in future. Thus, for them the concessions on payment terms were not balanced by a vision of future profits. ${ }^{48}$

It is submitted that the availability and effectiveness of judicial remedies affects the attitude of creditors towards restructuring negotiations and the ultimate result of the negotiations. The absence of a formal insolvency regime and regulatory oversight makes holdout litigation, in connection with informal means of political or market pressure, the only formal check on the debtor country's opportunistic behaviour.

The existence of holdout creditors serves as a control on opportunistic defaults and unreasonable workout terms or can help to prevent discrimination against minority creditors. On the other hand, holdouts are more often viewed as an obstacle to orderly restructuring, thus burdening majority creditors and citizens of the debtor country. As sovereign bonds are contracts with a State that are governed by law of a particular jurisdiction, usually with a forum selection clause, the readily available option for creditors who do not want to participate in the restructuring is litigation according to the submission clause in the debt instrument. The case law of US and English courts, the most common jurisdictions used, prove that it is possible to obtain a favourable judgment holding the State liable for non-payment. ${ }^{49}$ Nevertheless, the usual lack of attachable assets abroad and immunity from execution that applies in certain cases may pose obstacles for a successful court action. ${ }^{50}$ Hence, it is not surprising why voluntary renegotiation of debt is still the primary method for solving sovereign debt disputes. ${ }^{51}$ In other words, the main problem with judicial action against a sovereign entity is the lack of reliable enforcement mechanisms. ${ }^{52}$

48 Fisch and Gentile, supra nt 37, 1063.

49 See eg., United States District Court, Allied Bank International v Banco Credito Agricola de Cartago, 566 F Supp 1440, 1442 (SDNY 1983); United States Court of Appeal, Libra Bank Ltd v Banco Nacional de Costa Rica, $S A$, F2d 47, 49 (2d Cir 1982).

50 An illustrative example of the fruitless yet inventive approaches to enforcement of sovereign assets is the seizure of Argentine frigate ARA Libertad by the NML Capital, which was eventually released following a judgment from the International Tribunal of the Law of the Sea (ITLOS), The " $A R A$ Libertad" Case (Argentina v Ghana), Case No 20, Order, 20 November 2012.

51 ILA, State Insolvency, supra nt 5, 5. Most of the bond instruments include waivers of sovereign immunity from jurisdiction, but some also include immunity from execution, eg., Brazilian bonds that use arbitration clauses: Halverson Cross 2006, supra nt 33, Appendix I; see also Schlemmer, supra nt 43

52 Apart from the NML Capital Ltd $v$ Republic of Argentina, one example of particularly successful litigation strategy is the now notorious United States District Court for the Southern District of New York, Elliott Assoc v Republic of Peru, 948 F Supp 1203 (SDNY 1996); United States District Court for the Southern District of New York, Elliott Assoc v Republic of Peru, 961 F Supp 83 (SDNY 1997); United States District Court, Elliott Assoc v Republic of Peru, 12 F Supp 2d 328 (SDNY 1998); United States Court of Appeals, Elliott Assoc v Republic of Peru, 194 F 3d 363 (2d Cir 1999); United States District Court, Elliott Assoc v Republic of Peru, 194 FDR. 116 (SDNY 2000); Court of Appeals of Brussels, Elliot Assocs, LP v Banco de la Nacion, General Docket No 2000/QR/92, (8th Chamber, 26 September 2000). Elliott obtained a distressed debt owed by Peru at a discounted price shortly before Peru was about to reach the Brady deal in 1996. After several attempts, it obtained prejudgment attachment of assets and a judgment against Peru from New York courts. A new element for enforcing this judgment was that Elliott did not only attempt to attach Peruvian assets in various jurisdictions but also tried to prevent payment of interests on negotiated Brady bonds which flowed from the restructuring agreement. Before the Brussels Court of Appeals it managed to suspend payments from Euroclear, a clearing agency providing payment from Brady bonds. Under a threat of default on the newly negotiated Brady bonds, Peru decided to settle with Elliot when the due date was approaching. If this strategy were to become a rule, holdout creditors would become a systemic problem preventing any orderly restructuring. Harvard Law School International Finance Seminar, Lopez Sandoval, EL, Sovereign Debt Restructuring: Should we be worried about Elliot?, May 2002, at <law.harvard.edu/programs/about/pifs/education/11m/2001--- 
It has been argued that if the major distortion in sovereign debt is lack of contract enforcement, then improvements in creditor rights should be in the interests of both sides. ${ }^{53}$ Nevertheless, it is also recognised that this does not necessarily apply when some creditors use legal action in order to get an advantage over other creditors, thus stopping cooperation between each other. ${ }^{54}$ This is exactly the problem of holdouts. Investment arbitration has so far been utilised as one of the fora used for enforcement rights of holdouts. It is worth noting, however, that the ultimate and most efficient check on the State's attitude is its ability to access the market for further financing. This incentive has so far proved to be the most important.

\section{II.3.1. Methods of Addressing the Issue of Holdouts}

A reasonable solution to the situation of debt servicing difficulties of a country must reflect a country's capacity to pay. The prospects of successfully holding out should not be too high in order not to prevent an orderly restructuring. Nevertheless, States should be aware that they cannot entirely escape their debt obligations and therefore certain leverage left for non-cooperative creditors is a sensible solution for avoiding opportunistic and irresponsible State behaviour. To avoid the holdout issue entirely without comparable enhancement of creditors' rights is not a good solution, as it entices 'moral hazard' on the part of the State. The question is in keeping the holdout problem within limits. The authors defending positive effects of holdouts point out that especially effective coordination and representation of dissenting creditors should be improved. ${ }^{55}$ However, as we pointed out, States themselves have a great incentive to retain their credibility as debtors as this only can secure them market access. The holdout problem can be reasonably tackled through various methods.

\section{II.3.1.1. Collective Action Clauses (CACS)}

This purely contractual method is now becoming a standard means to address the holdout problem in debt instruments. ${ }^{56}$ These clauses allow, after an agreement between the debtor and a certain percentage of creditors of one bond issue (usually $75 \%$ and more), modifications of the payment terms of the bond issue, including face value, interest and maturity, that are also binding on non-participants.

CACs are designed to avoid free riding and they are used as incentives for better coordination between creditors and for enhancement of the efficiency of restructuring negotiations. They usually incorporate provisions on collective bondholders' representation, majority restructuring provisions and components on minimum

2002/sp44.pdf> (accessed 7 April 2015), 26; Olivares-Caminal, R, "To Rank Pari Passu or Not to Rank Pari Passu: That is the Question in Sovereign Bonds after the Latest Episode of the Argentine Saga" 16 Law and Business Review of Americas (2003) 745. A similar strategy was rejected by Belgian courts in LNC $v$ Nicaragua; English courts in Kinsington v Democratic Republic of Congo; Red Mountain Finance v Democratic Republic of Congo (ibid). However, US court decisions in the recent litigation by NML $v$ Argentina (an offshore unit of Elliot Associates) shows resurrection of this questionable legal logic.

53 Sturzenegger and Zettelmeyer, supra nt 17, 62.

54 Ibid.

55 Fisch and Gentile, supra nt 37, 1106. They propose provision on, eg., fiscal agency, trust indentures, minimum percentages to commence litigation or even limiting the class of eligible bondholders.

56 Collective Action Clauses (CACs) can be found in more than $90 \%$ of new bond issues, UNCTAD, Sovereign Debt Restructuring, supra nt 34, 6. 
enforcement percentages of bondholders that must be achieved in order to initiate holdout litigation. ${ }^{57}$

Although the use of CACs has not been yet properly tested in litigation, it has been argued that CACs may limit holdout adjudication in the way that they additionally prevent successful invocation of an International Investment Agreement (IIA) arbitration. First, once workout is achieved according to the CAC the terms of the original bond have been lawfully changed. Second, the minimum enforcement component can be argued to be interpreted as covering any kind of dispute settlement. ${ }^{58}$ One of the issues that has been pointed out as not entirely susceptible to be addressed by CACs is a problem of aggregation - how to make bond instruments of one issue regulate other bond issues of the same issuer. The limits of this purely contractual device are evident when tackling this problem. ${ }^{59}$

\section{II.3.1.2. Exit Consents}

So-called 'exit consent' is a method that utilises the existing amendment clauses in bond instruments in a way that they encourage the holdouts to participate in the exchange. The amendment clauses generally allow with agreement of the issuer and certain percentage of creditors (e.g. usually from 50-70\%) to change certain terms of the debt. However, these changes cannot affect the payment terms, such as the due date or the amount of principal or interest rate. The borrowing country may therefore make the creditors participating in the exchange also agree (exit consent) on the changes (exit amendments) in the old bonds so to make them less attractive and induce the holdouts to take part in the exchange. The amendments are in the interest of both the majority bondholders and the issuer. Although not being tested in practice, these amendments, it has been suggested, can go as far as changing the governing law of the bond or eliminating provisions on acceleration. Other options are, for example, removing immunity waivers, forum selection clauses, negative pledges, or provisions obliging the issuer to list the bonds on the exchange, thus reducing bonds' liquidity. This method has been used in three recent restructurings of sovereign debts (Ecuador 2000, Uruguay 2003, Dominican Republic 2005). ${ }^{60}$

\section{II.3.1.3. International Bankruptcy Procedure - SDRM}

The boldest out of the proposals designed to solve the issue of holdouts and other pertinent problems of international law on sovereign insolvency is a statutory regime resembling an international bankruptcy procedure. Such a proposal has been recently

57 See eg., European Union, Euro area Model CAC 2012, at <europa.eu/efc/sub_committee/cac/cac_2012/index_en.htm> (accessed 7 April 2015).

58 UNCTAD, Sovereign Debt Restructuring, supra nt 34, 6: Arguably, if a Bilateral Investment Treaty (BIT) offer to arbitrate that can be reads as 'any dispute arising out of an investment', meaning covering both treaty and contract claims, why cannot a similar provision in a contract have the same effect? CfHan, Y and Han, SD, "Sovereign Debt Restructuring under the Investor-State Dispute Regime", 31 Journal of International Arbitration (2014) 1, 75, 83: who argue that 'such exclusion ought to be express and specific'. However, the incongruity of this argument is shown, as in one instance they claim that specific types of debt instrument must be included in the general definition of investment in the BIT unless they are explicitly excluded, and in another instance they claim that CACs should not bind minority creditors regarding ICSID arbitration as long as this is not made explicit.

59 Eichengreen, B and Mody, A, "Is Aggregation a Problem for Sovereign Debt Restructuring?", 93(2) Economic Review (2003).

60 See eg., Buchheit, LC and Gulati, M, "Exit Consents in Sovereign Bond Exchanges", 48 UCLA Law Review (2000) 59; Sturzenegger and Zettelmeyer, supra nt 17, 62. 
made by the $\mathrm{IMF}^{61}$ and was subsequently rejected. It does not seem that any similar reform is on the table for the time being. It is evident that statutory solution to international bankruptcy is politically very difficult to put through. The system was supposed to be based on a multilateral international convention and supplemented by IMF Article amendments. It would provide for a statutory regime of State insolvency dispute settlement forum with institutional support of the IMF. States would be able to file for restructuring proceedings, whereby ensuing restructuring plans could be accepted by majority of creditors and binding on dissenters. It would allow for stay of enforcement proceedings against the State, creditors' priority rules and would provide for a mechanism for provision of new money by private creditors with necessary protective measures. The proceedings would be followed by IMF suggested policies to be implemented for protecting the debtor's capacity to pay. ${ }^{62}$

\section{II.3.1.4. Holdout Arbitration}

In current practice, arbitration is not a widely used method of resolving holdout disputes arising from sovereign bonds. A notable exception is Brazil, whose bonds as a rule include arbitration clauses. ${ }^{63}$ Several reasons why litigation is preferred over arbitration in the sovereign bond disputes arena may be identified. ${ }^{64}$ It might be the creditors' fear of equitable considerations playing larger role in arbitration, lack of appeal and lower predictability, availability of summary judgments and interim relief in litigation and finally the 'lock-in' effects of standardised 'boilerplate' contracts used in the financial markets.

In investment arbitration, and arbitration in general, the debtor-State has certain influence over the composition of the tribunal deciding the case. This might be one of the reasons for creditors' preference of 'tested' domestic courts. Conversely, this may be a reason for States to include arbitration clauses. Even with the apparent enforcement advantage over the domestic judgment of international awards, particularly in the case of ICSID Convention, the issue of immunity from execution remains applicable even in this case. ${ }^{65}$ As far as the New York Convention is concerned, the grounds for refusal of

61 Krueger, AO, A New Approach to Sovereign Debt Restructuring (International Monetary Fund, USA, 2002).

62 Ibid; for further discussion see eg., Eulis, R, “The Feasibility of the IMF's Sovereign Debt Restructuring Mechanism: An Alternative Statutory Approach to Mollify American Reservations", 19(1) American University International Law Review (2003) 107.

63 Halverson Cross 2006, supra nt 33, 341. Historically, however, arbitration clauses have been used in sovereign debt instruments, although they have been barely complied with. Arbitration clauses began to appear in the sovereign debt instruments for loans provided by private creditors particularly from the US and the UK to Latin American and Caribbean States in the first decades of 20th century. See Weidemaier, MC, "Contracting for State Intervention: The Origins of Sovereign Debt Arbitration", 73 Law and Contemporary Problems (2010) 335. One theory explains the early use of arbitration clauses in the late 19th and the first half of 20th century not as a means of settling disputes, but as a projection of power of creditors from industrialised countries. Weidemaier notes that some arbitration clauses referred the disputes directly to the official of the national state of the lender, eg., the US Secretary of State Id 344. Thus, the arbitration clauses were rather used to signal the readiness of a third party, a national state, to intervene if the obligations were not fulfilled. The author also links this practice with conclusion of Drago-Porter Convention which precluded use of force for recovering debts, but not in cases when a borrowing country refused to arbitrate.

64 Halverson Cross 2011, supra nt 36, 6-7, 51; Waibel, supra nt 2, 163; Weidemaier, MC, "Disputing Boilerplate", UNC Legal Studies Research Paper No 1158611 (July 2008), at <ssrn.com/abstract=1158611> (accessed 26 April 2015).

65 Article 55, Convention on the Settlement of Investment Disputes between States and Nationals of Other States (1965) 4 ILM 524 (ICSID Convention). Schlemmer, supra nt 43, 443; Where the author argues for not granting immunity from execution in cases of arbitration based on the principle of estoppel (waiver of 
enforcement, especially on public policy grounds in Article V, can also provide a certain leeway for the State not to make the award enforceable.

Advantages of treaty arbitration may, however, become particularly strong in cases where a debt instrument lacks any forum selection clause. ${ }^{66}$ Although, this situation can be regarded as marginal, the Greek economic crisis makes this scenario closer to reality, as the majority of the restructured Greek bonds are governed by Greek law and thus disputes are submitted to the courts of Athens. ${ }^{67}$ It is rather probable that Greek courts would not be particularly receptive to the claims of bondholders against their government. ${ }^{68}$ Yet, the prospect of holdout investment arbitration against Greece has so far proved not to be of major concern. ${ }^{69}$

\section{Investment Arbitration and Disputes over Sovereign Defaults}

The present part of the article addresses the applicability of the regime of investment arbitration on disputes arising from defaults on sovereign bonds. The trio of Argentine bondholders' cases will serve as a basis for the discussion. Due to the limitations of space, this part will only critically examine the treatment of the ratione materiae jurisdictional threshold. Other pertinent issues the triplet of decisions have raised are left out. ${ }^{70}$

\section{III.1. Ratione Materiae Jurisdiction of the Centre}

Article 25 ICSID defines the jurisdiction of the Centre as covering 'any legal dispute arising out of an investment.' This sentence defines the subject-matter jurisdiction of the Centre, and the term 'investment' is crucial here. Even though this term is not defined in

immunity from jurisdiction by agreement to arbitrate should imply also waiver of immunity from execution).

66 Wälde, supra nt 9, 403.

67 Choi, SJ, Gulati, M and Posner, EA, "Pricing Terms in Sovereign Debt Contracts: A Greek Case Study with Implications for the European Crisis Resolution Mechanism", University of Chicago Olin Law and Economics Working Paper No 541, (1 February 2011), at <papers.ssrn.com/sol3/papers.cfm?abstract_id=1713914> (accessed 7 April 2015).

68 It can be argued, however, that dissatisfied creditors may try to utilise the enforcement mechanisms provided by the EU legal framework; see eg., Glinavos, I, "Investors vs. Greece: The Greek "Haircut" and Investor Arbitration Under BITs", (May 2012), at <papers.ssrn.com/sol3/papers.cfm?abstract_id=2021137> (accessed 7 April 2015), 12.

69 The participation in the Greek sovereign debt restructuring through the statutory insertion of collective action clauses led to $95,7 \%$ participation. Holders of bonds governed by English law were settled separately, thus the possibility of holdout arbitration remained negligible. Norton, E, "International Investment Arbitration and the European Debt Crisis", 13 Chicago Journal of International Law (2012) 291.

70 One of the most debated issues was consent to mass claims proceedings. For discussions see eg., Demikrol, B, "Does an Investment Treaty Tribunal Need Special Consent for Mass Claims?" 2(3) Cambridge Journal of International and Comparative Law (2013) 612; Steingruber, AM, "Case Comment Abaclat and Others v Argentine Republic: Consent in Large-scale Arbitration Proceedings", 27(2) ICSID Review (2012) 237; van Houtte, H and McAsey, B, "Case Comment - Abaclat and Others v Argentine Republic: ICSID, the BIT and Mass Claims" 27(2) ICSID Review (2012) 231; Strong, SI, "Heir of Abaclat? Mass and Multiparty Proceedings: Ambiente Ufficio SPA v Argentine Republic", 29 ICSID Review (2014) 149; Bees, J und Chrostin, J, "Sovereign Debt Restructuring and Mass Claims Arbitration before the ICSID: The Abaclat Case", 52(2) Harvard International Law Journal (2012) 505; Strong, SI, "Mass Procedures in Abaclat $v$ Argentine Republic: Are They Consistent with the International Investment Regime?", 3 Yearbook on International Arbitration (2013) 261. 
the Convention, the majority view, as expressed in case law and doctrine, is that the term has an objective meaning, although it is encompassing and inclusionary. ${ }^{71}$ The prevailing view is that the use of the term investment in Article 25 of ICSID provides for 'outer limits $^{72}$ or a 'hard core' 73 of the jurisdiction of the Centre.

However, the general adherence to the objective approach leaves open the question as to how to determine the objective core. ${ }^{74}$ Elements of an investment developed by tribunals differ from case to case. They vary from a liberal approach (contribution with money or assets, element of risk, certain duration $)^{75}$ to rather a bold list of requirements (contribution of money or assets, certain duration, element of risk, investment made in order to develop an economic activity in the host State, investment made in accordance with host State; investment made in good faith). ${ }^{76}$

There are also views which hold that the agreement between two States as to the definition of an investment materialised in the BIT should trump any perceived limitations of Article $25 .{ }^{77}$ The arguments used in support of this position are purportedly pragmatic considerations, or are based on selective arguments from the drafting history of the Convention and implicitly on purported evolutionary interpretation of the ICSID. ${ }^{78}$ This subjectivist view is not supported in this article. The fact that BITs use varying definitions shows that there is a lack of common understanding of the term, and therefore that BITs cannot be used individually or in aggregate to determine the content of the term as used in ICSID. ${ }^{79}$ In this respect, a multilateral character of ICSID should be considered ${ }^{80}$ IIAs are usually concluded on a bilateral basis and reflect an understanding of what should be treated as an investment as between the contracting parties. This bilateral concept cannot have a transforming effect on the terms used in a multilateral

71 Salini Costruttori SpA and Italstrade SpA v Kingdom of Morocco, ICSID Case No ARB/00/4, Decision on Jurisdiction, 31 July 2001, para 44 (Salini $v$ Morocco);, Phoenix Action Ltd $v$ The Czech Republic, ICSID Case No ARB/06/5, Award, 6 April 2007 (Phoenix Action Case); Fedax NV $v$ The Republic of Venezuela, ICSID Case No ARB/96/3, Decision on Objections to Jurisdiction, 11 July 1997 (Fedax Case); Mr Patrick Mitchell v Democratic Republic of the Congo, ICSID Case No ARB/99/7, Decision on Annulment, 1 November 2006; Schreuer, C, The ICSID Convention: A Commentary (2nd ed, Cambridge University Press, Cambridge, 2009), 117; Broches, A, "The Convention on the Settlement of Investment Disputes between States and Nationals of Other States", 132(8) Recueil des Cours (1972) 330; Mortenson, JD, “The Meaning of 'Investment': ICSID's Travaux and the Domain of International Investment Law”, 51(1) Harvard Journal of International Law (2010) 257; Waibel, supra nt 2, 215.

72 Broches, supra nt 71, 330.

73 Abaclat and others $v$ Argentine Republic, ICSID Case No ARB/07/5, Dissenting Opinion of Professor AbiSaab, 4 August 2011, para 46 (Abaclat, Dissenting Opinion).

74 Schreuer, supra nt 71; Waibel, supra nt 2; Douglas, Z, The International Law of Investment Claims (Cambridge University Press, Cambridge, 2009), 191.

75 Saba Fakes $v$ Republic of Turkey, ICSID Case No ARB/07/20, Award, 14 July 2010, para 110; LESIDipenta $v$ Algeria, ICSID Case No ARB/03/8, Award, 10 January 2005, para II.13(iv).

76 Phoenix Action Case.

77 Abaclat, paras 364-365; Malaysian Historical Salvors, SDN, BHD v Malaysia, ICSID Case No. ARB/05/10, Annulment, 16 April 2009, para 73 (MHS); Krishan, D, “A Notion of ICSID Investment," 6(1) Transnational Dispute Management (2009) 14.

78 In Abaclat, the majority held that it would be against the 'spirit' of ICSID to create limits, which neither the ICSID Convention nor the Parties to the BIT intended to create. Thus, the only relevant criterion is that the investment creates a value protected by the BIT (paras 364-365); MHS, para 73. The Committee stated that IIAs are currently the main basis of the caseload before ICSID and to disregard definitions used therein would risk crippling the institution.

79 Waibel, supra nt 2, 217; Dolzer, R, "The Notion of Investment in Recent Practice" in Charnovitz, S, Steger, DP and Van Den Bossche, P, eds, Law in the Service of Human Dignity: Essays in Honour of Florentino Feliciano (Cambridge University Press, Cambridge, 2005), 263.

80 See Waibel, supra nt 2, 214-215, Phoenix Action Case, para 96. 
convention. If the BIT definition goes beyond the requirements of ICSID there is no jurisdiction. ${ }^{81}$ In this respect, it is appropriate to add that ICSID is an adjudicative mechanism of a specialised jurisdiction, therefore the variety of disputes submitted to it cannot be limitless and be left solely to the parties' consent. ${ }^{82}$ The fact that the term was intentionally left undefined does not mean it has no meaning, or that the meaning can be filled based solely on what the parties to the BIT or a dispute agree on. This would effectively mean merging the requirement of a 'dispute arising out of an investment' with the requirement of written consent to arbitration. ${ }^{83}$

As this article supports the objective reading of the term investment in Article 25, the so-called double-barrelled test is considered to be applicable in any ICSID arbitration: the nature of the transaction or right in question has to fall both within the ambit of Article 25 of ICSID and also under the bilateral definition of the applicable BIT. ${ }^{84}$

Schreuer has extracted from the case law, ICSID interpretation and the drafting history five typical characteristics of investments. ${ }^{85}$ First, the investment should have certain duration and should be expected to be long-term; the second characteristic is a certain regularity of profit and return; thirdly, the assumption of risk, which is usually shared by both sides; fourth, the commitment of resources should be substantial; and last but not least, is the requirement extracted from the Convention's object and purpose, and that is the contribution to the host State's development. ${ }^{86}$ Schreuer further adds qualification as far as the regularity of profits is concerned: he claims that most tribunals have not applied this requirement as critical. Douglas stresses the interaction between legal and economic characteristics of an investment, whereby the legal dimension means that an investment should have a character of property right situated in the territory of the host State, economic characteristics retain only three of the above stated characteristics. These are commitment of resources, assumption of risk and expectation of return. ${ }^{87}$ Other authors add necessity of connection with a certain commercial undertaking and emphasise the need for the requisite territorial link. ${ }^{88}$

The present author agrees and submits that the issue of sovereign bonds will not raise any issue as far as duration is concerned; the fact of trading on the secondary market should not change the conclusion. Sovereign bonds mature on an agreed period in the debt instrument, a period which is usually long enough to be in line with the case law varies between two and 30 years. Nevertheless, a bondholder as a claimant in investment arbitration must be considered an investor. On the secondary market, bonds can change owners after a very short time - should this influence the decision on jurisdiction of the tribunal? Fedax tried to distinguish the transaction in question (which was a promissory note issued by Venezuela) from volatile capital that 'come[s] in for quick gains and leave[s] immediately thereafter. ${ }^{89}$ By arguing that, even in case of every other

81 Schreuer, supra nt 71, 124.

82 Ambiente, para 439. However, dissenting arbitrator Torres Bernárdez accuses the majority of adhering to the subjectivist theory: Ambiente, Dissenting Opinion, paras 190-201.

83 Gaillard, E, "Indentify or Define? Reflections on the Evolution of the Concept of Investment in ICSID Practice" in Binder, C, ed, International Law for the 21st Century: Essays in the Honour of Christoph Schreuer (Oxford University Press, Oxford, 2009), 410.

84 See eg., Schreuer, supra nt 71, 117; MHS, para 55; ČSOB v Slovakia, ICSID Case No ARB/97/4, Decision on Objections to Jurisdiction, 24 May 1999, para 66-68 (ČSOB).

85 Schreuer, supra nt 71, 128-129.

86 Originally formulated in Fedax Case and subsequently in Salini v Morocco.

87 Douglas, supra nt 74.

88 Waibel, supra nt 2, 231.

89 Fedax Case, para 43. 
endorsement of a promissory note, Venezuela enjoys continuous credit benefit, the Fedax tribunal fails to elaborate on how this volatile capital should in fact be identified in practice.

Likewise, the criterion of the contribution of economic development is left out from our inquiry. This is mostly for its subjective nature and incapability of being transposed into an operational legal test. ${ }^{90}$ Although ideally a protected investment should contribute to the economic development of the host State, it is affirmed here with the opinions that see difficulties arising from operationalisation of this criterion in the proceedings. ${ }^{91}$ The article submits that contribution to the economic development of the host State does not need to be included in the test for identification of an investment under ICSID as a separate criterion. If there are the above analysed requirements in the form of commitment of capital, having the necessary territorial link and connection with certain economic activity, shared risk and certain duration, and they are made for the commercial return, they should qualify for under Article 25.

\section{III.1.1. Sovereign Bonds as an Investment under ICSID}

It has been argued that the understanding of the concept of investment in financial markets differs from the definition used in a foreign investment context. ${ }^{92}$ The question whether sovereign debt instruments, like bond security entitlements, fall within the ambit of Article 25 of ICSID is a question of treaty interpretation, not an issue of consent. ${ }^{93}$ Investment case law has deemed financial instruments to be a protected investment in the majority of cases where such instruments were under scrutiny. Therefore, promissory notes $^{94}$ and loans ${ }^{95}$ have been deemed to be covered. Decisions ruling to the contrary, however, have also been rendered. ${ }^{96}$ Lengthy pages have been occupied in the Abaclat, Ambiente and Alemanni decisions, and in the subsequent literature by the analysis of how wide the 'outer limits' of the ICSID investment are. The present article, however, adopts the view that the sovereign debt securities such as those under scrutiny in the Argentine cases are outside of the ambit of ICSID and the applicable BIT for much more prosaic and technical reasons - that is because they are not located within the territory of Argentina and do not exhibit the requisite investment risk.

\section{III.1.1.1. Territoriality Requirement}

It has not been contested that commitment of money or other resources is one of the essential elements of an investment. In case of sovereign bonds traded on the secondary market, there are two connected issues. First of all, it is whether the resources invested by the bondholder must be transferred to the host State, in other words if there is any necessity for a territorial link. ${ }^{97}$ And second, must the transaction to which the

90 Dissenting arbitrators in Abaclat and Ambiente both took issue with both of these requirements. Yet, their arguments have much less force than their other points relating to territoriality and risk sharing.

91 Douglas, supra nt 74, 202; Waibel, supra nt 2, 234; LESI-Dipenta.

92 Waibel, supra nt 2, 217; see also Dolzer, supra nt 79, 261; Abaclat, Dissenting Opinion, para 41.

93 Waibel, supra nt 2, 213; Joy Mining Machinery Limited v Egypt, ICSID Case No ARB/03/11, Award, 6 August 2004, para 49 (Joy Mining); Abaclat, Dissenting Opinion.

94 Fedax Case.

$95 \check{C} S O B$; Sempra Energy International v Argentina, ICSID Case No ARB/02/16, Decision on Objections to Jurisdiction, 11 May 2005, paras 214-216.

96 Joy Mining, paras 42-50; PSEG Global v Turkey, ICSID Case No ARB/02/5, Decision on Jurisdiction, 4 June 2004, para 189.

97 Douglas, supra nt 74, 191: Douglas sees it as one of the aspects of economic materialisation of an investment. 
bondholder is a party, standing alone, qualify as an investment? The former issue arises also due to the territorial requirement under IIAs, ${ }^{98}$ and the latter one is often subsumed under the heading of 'dispute arising directly out of an investment' in the ICSID Convention.

Waibel stresses the importance of the question of whether it is sufficient for bonds to qualify as an investment at issuance, or if it is necessary that a purchase of a security entitlement on the secondary market must qualify as an investment too. Although Fedax and $\check{C} S O B$ (cases cited by the Argentine bondholders' tribunals) seem to answer the question in the negative, he claims that it should be answered affirmatively as this is the only transaction to which the bondholder is a party. ${ }^{99}$ The case law shows that even when a particular transaction, which is the subject-matter of a dispute, in and of itself, does not qualify as an investment, the jurisdiction of the tribunal is upheld when this transaction is part of a larger investment operation that is considered to be an investment. ${ }^{100}$ Schreuer concludes that when an ancillary but vital transaction is made in a separate form or even between separate entities, this does not deprive it of a direct relation to the investment. ${ }^{101}$

The Abaclat, Ambiente and Alemanni cases stress that the security entitlements cannot be viewed in isolation and that they make sense only when the economic transaction of bond issuance and subsequent trading of security entitlements is viewed as a whole. ${ }^{102}$ These decisions overemphasise the concept of 'economic unity' in disregard of important legal principles that should guide them.

First of all, in Abaclat, Ambiente and Alemanni the bondholders were only party to the secondary market purchase, not to the rest of the transactions. The Tribunal dealt with the question in a way which treated security entitlements as a separate investment. However, if the security entitlement does not separately qualify as an investment (as our analysis below shows), there is a problem of the lack of personal jurisdiction. This is because, in order to become an investor, one needs to hold an investment. The Argentine cases seem to disregard factual as well as legal characteristics of the financial markets and the underlying transactions. It is certainly a stretch to treat two transactions that are operating on the different markets, with different actors, different dynamics and different legal frameworks as having 'economic unity', something which dissenting arbitrators rightly pointed out. ${ }^{103}$

Second, the theory of economic unity has a rather dubious legal basis and disregards legal characteristics of the transactions at hand. While, as a tribunal deciding according to law, it should be guided by these characteristics. If the claimants hold security entitlements and these are the only assets that might form the investment, we need to determine whether these are indeed situated within the territory of Argentina. This is made more important by the fact that this requirement is explicitly stated in both the ICSID Convention and in the applicable BIT. The rationale behind the BITs is to reduce the sovereign risk associated with a State's enforcement jurisdiction. ${ }^{104}$ This is why,

98 Eg., Article 1(1), Argentina-Italy BIT (1993).

99 Waibel, supra nt 2, 218.

100 Eg., Holiday Inns v Morocco, ICSID Case No ARB/72/1, Decision on Jurisdiction, 12 May 1974; ČSOB, para 72. For a contrary conclusion focusing instead on the transaction of the dispute see Joy Mining, paras $42-50$.

101 Schreuer, supra nt 71, 112 [emphasis added].

102 Abaclat, para 358; Ambiente, para 327.

103 Abaclat, Dissenting Opinion, paras 69-72; Ambiente, Dissenting Opinion, paras 153-161.

104 Douglas, Z, "Property, Investment and the Scope of Investment Protection Obligations" in Douglas, Z, Pauwelyn, J and Vinuales, JE, The Foundations of International Investment Law: Bringing Theory into Practice (Oxford University Press, Oxford, 2014), 23. 
whenever a contractual right is a protected investment, it must be legally located in the host State. This determination must be made according to the rules of private international law, which determine the situs of the transaction in question. ${ }^{105}$ The problem with the decisions in Abaclat, Ambiente and Alemanni is that they willfully disregard the applicable rule of private international law that the situs of a contract is 'where it is properly recoverable or can be enforced ... In respect of securities which are "immobilised" or "immaterialised" by their deposit within the international clearing and depository system.' ${ }^{106}$ For the tribunals, what matters is for whose benefit the funds are ultimately available; the so-called concept of continuous credit benefit - a controversial dictum taken from Fedax.

Apart from the disregard of the principle of territorial jurisdiction and the private international principle determining the situs of securities, Douglas mentions another problem with the way in which the Argentine bondholders' tribunals treated the territoriality requirement. This is that the test of 'continuous credit benefit' cannot be applied as a general rule without leading to absurd results. If this test were to be used to establish the requisite territoriality,

Then the purchase of Argentine beef from an Argentine state-owned distributor in Italy would be capable of constituting an investment in Argentina, as would the purchase of a visa to travel to Argentina at its consulate in Rome, as would the purchase of a ticket to fly from Rome to Buonos Aires on Aerolíneas Argentinas. ${ }^{107}$

The three tribunals attempted to mask this problematic proposition by relying on the previous case-law relating to the debt instruments. However, upon closer examination of the facts of the cases invoked, the far-reaching consequences drawn by the Argentine bondholders' cases are not supported. Certainly, the cited cases do not support articulation of a general principle of 'continuous credit benefit' credited to them.

The tribunal in $\check{C} S O B v$ Slovakia held that, although the loan in question did not cause any transfer of funds from the claimant to Slovakia, it was sufficient that this loan was an instrument in the overarching project of privatisation of a bank which qualified as an investment - a project to which the claimant was a party. Abaclat and Ambiente attempted to align with the decision of $\check{C} S O B$, stressing that the security entitlements cannot be viewed in isolation and make sense only when the economic transaction of bond issuance is viewed as a whole..$^{108}$

There are, however, two major factual differences between $\check{C} S O B$, on the one hand, and the Argentine cases on the other. First, in the Argentine cases, the bondholders were only party to the secondary market purchase, not to the rest of the transactions, and second, there is no connection with a particular economic project in the country. The tribunals do not see this fact as having any bearing on the decision as long as the money

$105 I d, 27$.

106 Ibid, referring to Collins, L, ed, Dicey, Morris and Collins on The Conflict of Laws (Sweet and Maxwell, London, 2006).

107 Id, 28: this result was also pointed out by the dissenting arbitrator in Ambiente, Dissenting Opinion, paras 181 and 188 .

108 Abaclat, para 358; Ambiente, para 327. 
is ultimately available to the host country. ${ }^{109}$ We have already established that there is no legal principle which would dictate application of this criterion.

It is true that a territorial link in the form of services being carried out in the territory of the State or in the form of funds transferred into the host State was not held to be a necessary precondition for jurisdiction in other cases related to debt instruments. Some authors view this as supporting the position in Fedax, therefore justifying treatment of instruments traded on the secondary financial markets as investments. ${ }^{110}$ However, this does not mean that there are no other governing principles at play.

In $S G S$ v Pakistan, the pre-shipment services were to be carried out outside Pakistan's territory by SGS' affiliates. Pakistan's arguments that the investment was not made within the territory of Pakistan were rejected. The Tribunal ruled that first, SGS' services gave rise to a 'claim to money' as covered under the BIT; second, Pakistan gave a public law concession to SGS, thus a 'right conferred by law' protected under the BIT; and third, SGS made certain payments directly in Pakistan. ${ }^{11}$ One can clearly see the existence of a concession right governed by the host State's law, hence clearly subjected to the territorial jurisdiction of the host State.

Similarly, in $S G S v$ Philippines, with the factual background largely resembling the Pakistani case, the Tribunal in addition stressed the purpose of the whole transaction as being an 'improvement of inspection and import services and associated customs revenue gathering [in the Philippines]. ${ }^{112}$ Yet, one should certainly not treat this as anything more than obiter.

The present author opines that the above-mentioned decisions cannot be held entirely applicable to the case of sovereign bonds. First, in Fedax as well as in the SGS cases, there was an underlying transaction to which the tribunals referred as being the overarching investment project and which was subjected to the host State's territorial jurisdiction. The promissory notes in Fedax were tied to the financing of a specific investment project and were governed by Venezuelan law; they were not abstract financial instruments providing funding of the general treasury. Similarly, SGS concession contracts were linked to particular commercial projects, even receiving the status of public law concessions. Bond contracts are not usually (and certainly not in the Argentine bondholders' cases) governed by the host State's law - the place of issuance is elsewhere - and the only link with the country is that the financing is transferred to the country's general treasury at the time of the issuance.

The particulars of the cases when applied to different circumstances should not be disregarded. Bond securities are difficult to locate in the territory of the host country. ${ }^{113}$ Professor Abi-Saab, in his dissenting opinion, stated that portfolio investments indeed cannot be excluded per se, but whether they fall within the ICSID jurisdiction must be ascertained in the circumstances of a particular case. ${ }^{114}$ The present author embraces this view. It behoves mentioning that the Alemanni tribunal dealt with the issue in a

109 Abaclat, para 375; Ambiente, para 503: where the majority states that the specificity requirement cannot be found anywhere in the BIT.

110 Alexandrov, SA, "The 'Baby Boom' of Treaty-Based Arbitrations and the Jurisdiction of ICSID Tribunals: Shareholders as 'Investors' under Investment Treaties", 6(3) Journal of Foreign Investment \& Trade (2005) 387, 408-409; Szodruch, A, supra nt 36, 149.

111 SGS v Pakistan, ICSID Case No ARB/01/13, Decision on Jurisdiction, 5 May 2004, paras 76, 134 and 135.

112 SGS v Philippines, ICSID Case No ARB/02/6, Decision on Objections to Jurisdiction, 29 January 2004, paras 100-112.

113 Szodruch, supra nt 36, 144.

114 Abaclat, Dissenting Opinion, para 61. 
somewhat different (one may say more appropriate), yet not entirely correct way. The tribunal stated that it is sufficient that the original asset held by underwriters was undoubtedly capable of falling within the ratione materiae jurisdiction. All other questions relating to the individual claimants were joined to the merits stage. ${ }^{115}$

\section{III.1.1.2. Element of Investment Risk}

Nor is the element of risk is treated unambiguously in the case law. Many tribunals stated that the risk required for investment should not be merely a commercial risk. ${ }^{116}$ The State's obligation to pay the principal and interest in bonds is fixed, unconditional and not tied to the success of any economic operation (unless one wishes to understand the functioning of the State as an economic operation, yet such broad analogies are seldom helpful in solving concrete cases). The only risk present is a risk of non-performance, a purely commercial risk that is inherent in any commercial transaction. Non-performance in this case is represented by a default. This risk is reflected in the price of sovereign lending in international financial markets. The Fedax tribunal got away with a brief statement that the existence of a dispute regarding repayment proves the existence of a risk. But the qualification of that risk is lacking, therefore it seems that for the Fedax tribunal, any risk suffices. If this is a material content of the risk criterion, then the criterion becomes superfluous, as it will be satisfied every time an investor brings a claim. Other tribunals found that risk is present in any long-term commercial transaction and this has been viewed as sufficient. ${ }^{117}$ The opinion advocated here is that the risk that is understood as necessary for an investment implies certain control of the investor over the success of the operation. In the case of bonds, the bondholder cannot influence whether the principal and interest is paid.

Several authors emphasised that the risk relevant for investment under Article 25 is a risk that is shared between the parties regarding a certain entrepreneurial project. ${ }^{118}$ This particular requirement shows that there exists a remarkable difference within the pool of portfolio debt investments. This difference explains the qualification needed where portfolio investments are concerned, as expressed in Professor Abi-Saab's dissenting opinion in Abaclat. ${ }^{119}$ Corporate bonds for instance show clear relation to the corporation in question. Similarly, the promissory notes scrutinised in Fedax could have been clearly documented as being connected with a particular project. On the other hand, sovereign bonds can only be connected with the host country's general treasury. Also Schreuer in his commentary states that the risk is usually shared..$^{120}$

The problem of bonds and security entitlements satisfying the criterion of operational risk led the dissenting arbitrator in Ambiente to reject even the original bonds issued by Argentina to the underwriters as protected investment. ${ }^{121}$ According to Torres Bernárdez, the majority's decision is circular, because it at once rejects a simple commercial

115 Alemanni, para 296-297.

116 Joy Mining, para 57.

117 Bayindir v Pakistan, ICSID Case No ARB/03/29, Decision on Jurisdiction, paras 134-136; MHS, para 112.

118 Waibel, supra nt 2, 237. See also Voss, J, "The Protection and Promotion of Foreign Direct Investments in Developing Countries: Interests, Interdependencies, Intricacies", 31 International and Comparative Law Quarterly (1982) 686.

119 Abaclat, Dissenting Opinion, para 61; Sacerdoti, G, "Bilateral Treaties and Multilateral Instruments on Investment Protection", 269 Recuiel des Cours (1997) 251, 307.

${ }^{120}$ Schreuer, supra nt 71, 128.

${ }^{121}$ Ambiente, Dissenting Opinion, paras 180-189. 
transaction such as sale of Argentine cars as investment and at the same time approves bonds as bearing a different type of risk. He states that

By issuing and selling in accordance with contemporary international practice, the Argentine Republic created and made circulate in effect "financial products" of her own as a means of getting in the primary market liquidity for funding the State's general budgetary needs. Once issued, Argentina received the money looked for by selling the said "product" to placement banks (or underwriters) who, in turn, resell generally the bonds to other banks or institutions ... ${ }^{122}$

He concludes that Argentina was hence acting as a commercial actor and was not 'hosting' any investment, merely selling a financial product. Accordingly, the risk is merely commercial. ${ }^{123}$ This clearly resonates with the above quoted Douglas' conclusions on Abaclat's treatment of the territoriality requirement. The results of applying what Torres Bernárdez calls the 'erroneous public interest test' are manifestly absurd and unreasonable, as they make every commercial dealing with a government an investment. $^{124}$

\section{III.1.1.3. Prima Facie Violation of the Treaty}

That the three tribunals started from the mistaken assumption about territoriality is manifest in their treatment of prima facie violations of the treaty, a requisite jurisdictional threshold. Particularly the Ambiente tribunal was seemingly at pains when reasoning in order to arrive at the affirmative conclusion. The majority admitted that the emergency legislation (the measure at hand) was not capable of altering the terms of legal rights and obligations arising from different laws and jurisdictions. ${ }^{125}$ But then the majority started to mention the potential impact of the legislation on the 'contractual equilibrium' which might have been unilaterally modified. As this equilibrium has been modified by a sovereign act, prima facie jurisdiction is satisfied. ${ }^{126}$ One is left to wonder how the contractual equilibrium might have been legally modified by the sovereign act in question, when legal rights and obligations as well as their regulatory framework remained intact.

The fact that there was an exercise of sovereign power is beyond dispute. However, the majority cannot answer how the link between this exercise and any modification of the contractual equilibrium came into existence, even assuming the facts are proved to be correct in the merits phase. This reasoning, when applied to an analogous situation between two corporate equals, says that when there is a contract between the two corporations, and the board of directors issues a resolution to the company's executives

$122 I d$, para 183.

123 He refers to Romak SAv The Republic of Uzbekistan, UNCITRAL, Award, 26 November 2009, paras 229230: where the tribunal stated

All economic activity entails a certain degree of risk. As such, all contracts - including contracts that do not constitute an investment - carry the risk of non-performance. However, this kind of risk is pure commercial, counterparty risk, or, otherwise stated, the risk of doing business generally. It is therefore not an element that is useful for the purpose of distinguishing an investment and a commercial transaction. An 'investment risk' entails a different kind of alea, a situation in which an investor cannot be sure of a return on his investment, and may not know the amount he will end up spending, even if all relevant counterparties discharge their contractual obligations.

124 Ambiente, Dissenting Opinion, para 181.

125 Ambiente, para 547.

126 Id, para 548. 
ordering them that the contract should not be performed, this very decision may constitute a violation of the contract, regardless of whether the contract has in fact been performed. ${ }^{127}$ The fact that the decision is by a sovereign changes nothing and nor does the treaty/contract distinction. ${ }^{128}$

To sum up, sovereign bonds and the security entitlements issued and circulated on their basis (at least those at issue in the Argentine bondholders' cases) suffer from conditions which make them legally unfit for satisfying two critical jurisdictional requirements, namely being invested 'in the territory of the host State' and exhibiting an element of 'investment risk.' This, in turn, also makes the prima facie violation difficult to establish.

\section{III.2. Sovereign Bonds under IIAs}

To answer completely whether sovereign debt restructuring issues can come under the scrutiny of an investment tribunal, it must be also determined if sovereign debt instruments are covered by a particular IIA. It is true that only in some cases of sovereign bonds, the problems discussed above will be rectified. The most widely used definition for IIAs is a broad asset-based open-ended definition that uses the terms along the lines of 'investment means every kind of asset', combined with an illustrative list. ${ }^{129}$ Sovereign bonds are intangible assets that are characterised as claims to money. ${ }^{130}$ They are in forms of debt as opposed to equity. A traditional open-ended asset-based definition without further qualifications is apt to include sovereign bond and security entitlements, however assuming that the territorial link and the element of risk are satisfied. ${ }^{131}$ Some IIAs provide for bonds explicitly in their illustrative lists, but provisions in various BITs differ regarding the treatment of debt instruments as investments and also regarding the coverage of a sovereign debt.

Some treaties, particularly US BITs, subject the types of assets in the illustrative list to typical characteristics of an investment, namely commitment of capital or resources, expectation of gain or profit and assumption of risk. ${ }^{132}$ Specifically with respect to bonds, debentures, other debt instruments and loans, US Model BIT 2012 contains an explanatory footnote stating that

127 That this fact might have implications on the obligation of good faith is another, but unrelated, matter.

128 Alemanni, para 300: The tribunal embraced in its cursory analysis the circular view that through a combination of governmental policy and legislative action - thus quintessentially sovereign acts the Republic of Argentina went beyond a mere failure to pay the sums contractually due to its creditors, and that this happened under circumstances which lay outside the normal legal remedies and controls that exist for the benefit of creditors in the case of private bankruptcy

Again, the question of how the contractual rights can be prima facie affected remains unanswered. States exercise sovereign power in multifarious ways. However one cannot conclude from that that the exercise has legal effects outside of the State's territory, even if that was intended.

129 Vandevelde, K, Bilateral Investment Treaties: History, Policy and Interpretation (Oxford University Press, Oxford, 2010) 125; See eg., Article 1(b), Netherlands-Czech Republic BIT(1991)

the term "investments" shall comprise every kind of asset invested either directly or through an investor of a third State and more particularly, though not exclusively ... iii. title to money and other assets and to any performance having an economic value.

130 Douglas, supra nt 74, 180. Many BITs also state 'bonds' in their lists.

131 This may be arguable in case of bonds such were the Greek Eurobonds governed by Greek law.

132 Article 1, definition of 'investment', US Model Bilateral Investment Treaty 2012, at $<$ italaw.com/sites/default/files/archive/ita1028.pdf> (accessed 9 April 2015). 
[s]ome forms of debt, such as bonds, debentures, and long-term notes, are more likely to have the characteristics of an investment, while other forms of debt, such as claims to payment that are immediately due and result from the sale of goods or services, are less likely to have such characteristics. ${ }^{133}$

Although this explanatory note does not really explain much, it may be debated whether sovereign bonds satisfy characteristics of an investment, namely the assumption of risk under the US Model BIT. Some US BITs also require claims to money for being covered to be associated with an investment in its own right. ${ }^{134}$

Other IIAs subject protection of a particular claim to money to associations with an economic activity and even certain duration. Thus, the Czech Republic-Denmark BIT protects investments as 'every kind of assets invested in the territory of the other Contracting Party in connection with economic activities and for the purpose of establishing lasting economic relations. ${ }^{135}$

NAFTA Article 1139 provides for an exhaustive list of types of assets. It covers only enterprise-based debts with qualifying original maturity of at least three years, which particularly exclude interests in State-enterprises. It also covers

interests arising from the commitment of capital or other resources in the territory of a Party to economic activity in such territory, such as (i) contracts involving the presence of an investor's property in the territory of the Party, including turnkey or construction contracts, or concessions, or (ii) contracts where remuneration depends substantially on the production, revenues or profits of an enterprise[.]

In addition NAFTA contains carve outs relating to commercial transactions. ${ }^{136}$ Sovereign bonds thus cannot qualify as an investment under NAFTA.

The India-Mexico BIT uses similar language to NAFTA Article 1139 and thus excludes debt instruments relating to the sovereign or to State enterprises. ${ }^{137}$ Several other treaties use a similar enterprise-based definition of investment as far as debt instruments are concerned. ${ }^{138}$ Explicit exclusion of sovereign debt instruments is less common, but can be found. ${ }^{139}$

133 Ibid.

134 Article 1(a)(iii), US-Argentina BIT(1991): 'a claim to money or a claim to performance having economic value and directly related to an investment'; Similarly see Article 1(6)(c), Energy Charter Secretariat, Energy Charter Treaty at <encharter.org/fileadmin/user_upload/document/EN.pdf> (accessed 9 May 2005).

135 Article 1(1), Czech Republic-Denmark BIT (1991-2009).

136 Chapter 11, Article 1139, North American Free Trade Agreement (NAFTA):

(i) claims to money that arise solely from

(i) commercial contracts for the sale of goods or services by a national or enterprise in the territory of a Party to an enterprise in the territory of another Party, or

(ii) the extension of credit in connection with a commercial transaction, such as trade financing, other than a loan covered by subparagraph (d); or

(j) any other claims to money.

137 Article 1(7), Mexico-India BIT (2007).

138 Article 1(d)(2), US-Bahrain BIT(1999).

139 See eg., Article 1(aa), Croatia-Azerbaijan BIT(2007): 'investment does not mean: a) bonds, debentures or other debt instruments to, or a debt security issued by, a Contracting Party or a State enterprise of a Contracting Party'; see also Article 1(a)(iii), Japan-Colombia BIT(2011). 
Portfolio investments in general are sometimes excluded from the treaty coverage altogether. Denmark-Poland BIT provides that the term 'investment shall refer to all investments in companies ... and giving the investor the possibility of exercising significant influence on the management of the company concerned. ${ }^{140}$

As noted above, many IIAs include the requirement that an investment is made in the territory of the other State. The three Argentine bondholders' cases seem to follow Fedax's debateable and legally incorrect 'continuous credit benefit theory' instead of having recourse to the established principles of private international law. ${ }^{141}$ Professor Abi$\mathrm{Saab}$ wrote in his dissenting opinion that fulfilment of the territorial requirement is not present as security entitlements are 'free-standing and totally unhinged'. ${ }^{142}$

Last but not least, certain IIAs provide for a specific regime for sovereign debt restructuring altogether. ${ }^{143}$ Those clauses often appear in recent IIAs, FTAs in particular, in the form of treaty annexes. The special regime usually limits the causes of action available to foreign investors in disputes relating to sovereign debt, namely to national treatment and MFN treatment. The regime also distinguishes between 'negotiated restructuring', where a certain percentage of creditors participate and non-negotiated one, where investor is subject to a cooling-off period. ${ }^{144}$ The latter distinction is not always present. ${ }^{145}$

To sum up, whether sovereign bonds and related security entitlements qualify as a protected investment under an IIA depends largely on the treaty applicable. Any generalisations beyond those mentioned above are difficult to draw. Nevertheless, it is submitted that fulfilment of the territorial requirement present in a large number of IIAs should be subject to careful scrutiny by arbitral tribunals in cases of sovereign bonds. We add that even in the absence of an explicit territoriality requirement in the treaty, this condition is always applicable, as BITs cannot protect investments, which are not located within the territory of their contracting parties.

\section{Policy Issues Arising from the Use of Investment Treaty Arbitration for Sovereign Debt Disputes}

Apart from the legal problems, there are several policy and institutional concerns that arise when discussing the application of investment treaty arbitration to sovereign defaults disputes. This final part bridges the first two parts of the paper and discusses the policy questions that are implicated by investment arbitration on sovereign bonds, both for the law of sovereign defaults and for the international investment regime.

It is important to stress that use of investment treaty arbitration for resolving sovereign debt disputes must be assessed within the broader framework of the sovereign insolvency

140 Article 1(1)(b), Denmark-Poland BIT (1990); Turkey Model BIT.

${ }^{141}$ There are other cases following Fedax' reasoning, eg., Inmaris Perestroika and ors $v$ Ukraine, Decision on Jurisdiction, ICSID Case No ARB/08/8, 8 March 2010, para 124; For an opposite ruling see, Gruslin v Malaysia, Award, ICSID Case No ARB/99/3, 27 November 2000, para 25.7; in the NAFTA Context: Canadian Cattlemen $v$ United States, Award on jurisdiction, UNCITRAL, IIC 316 (2008), 28 January 2008, para 144.

142 Abaclat, Dissenting Opinion, para 108.

${ }_{143}$ Annex G, United States-Uruguay BIT (2005); Annex 10-A, DR-CAFTA, Central America-Dominican Republic-United States FTA (2004); Annex 10-B, Chile-United States FTA (2003); Chapter 10, Annex 8, China-Peru FTA (1994).

144 UNCTAD, Sovereign Debt Restructuring, supra nt 34, 7-8; Article 10.1 and 10.8, Peru-Singapore FTA (2009).

145 Annex 10-A, DR-CAFTA, Central America-Dominican Republic-United States FTA (2004). 
debate. Investment arbitration can be, however, considered as only one of the tools possibly used in this field. To paraphrase the ILA Study group, the key question is whether sovereign defaults should continue to be exclusively dealt with by a voluntary agreement between the debtor State and creditors or if a backdrop statutory formal insolvency regime is needed, and also whether the rights of creditors should be strengthened. ${ }^{146}$ Investment arbitration cannot, for the time being, be utilised as a general international insolvency mechanism, but undoubtedly can contribute to reinforcing creditors' rights. It should be noted that this part does not claim to be conclusive on the issues discussed and rather attempts to emphasise the major policy concerns.

Under the current state of law, investment arbitration is at best to be utilised as another forum for holdout creditors where they can pursue their claims for full repayment. The question necessarily arising in this regard is whether it is desirable to reinforce creditors' rights in this manner and thus enhance the power of holdout creditors. Affirmative answer to this question presupposes positive effects of holdouts and also insufficient creditors' protection under the current regime. In contradistinction, a negative answer is based on the premise that holdouts are disruptive and prevent orderly sovereign debt workouts. However, a disagreement exists on the effects of augmentation of current creditors' rights. One view is that the reinforcement is necessary as a check on irresponsible State policies and sovereign over-borrowing. Without improving current creditors' remedies, States are induced into a moral hazard. ${ }^{147}$ Another position deems this unnecessary as it can lead into a hostage situation, when minority creditors that bought sovereign debt on discounted prices may exploit good faith creditors willing to go with restructuring. ${ }^{148}$

This paper claims that previous experience with sovereign defaults shows that motivation to regain the access to markets for further financing and the credibility loss connected with opportunistic defaults States are pushed to settle with their creditors on terms as favourable within their limits. However, if we presume that it is desirable to increase the enforceability of creditors' rights against sovereign States, what can be answered, nevertheless, is whether investment arbitration is actually apt to enhance creditors' protection and whether this dispute settlement mechanism is suitable for addressing the issue.

\section{IV.1. Suitability of Investment Arbitration for Solving Sovereign Debt Disputes}

Working on the presumption of desirability of augmenting protection of creditors' rights, this sub-chapter highlights main advantages and disadvantages of the utilisation of investment arbitration in the field.

\section{IV.1.1. Advantages - Enforcement Prospect and Bargaining Chip}

The main advantages pertain to the perceived improvement in enforcement combined with traditional advantages of arbitration, such as neutrality, efficiency and the possibility of choosing arbitrators. ${ }^{149}$ Additionally, it is claimed that as investment treaty arbitration decreases sovereign risk, it thus allows the debtor countries to achieve better credit

\footnotetext{
146 ILA, Sovereign Insolvency, supra nt 5, 5.

147 ILA, Sovereign Insolvency, supra nt 5, 45; see also Fisch and Gentile, supra nt 37.

148 ILA, Sovereign Insolvency, supra nt 5, 46; see also, Buchheit, LC and Gulati, M, "Sovereign Bonds and Collective Will", 51(4) Emory Law Journal (2002) 1317.

149 Halverson Cross 2006, supra nt 33, 339-341.
} 
terms. ${ }^{150}$ This can be, however, achieved rather in a long-term, once investment arbitration is tested over time. ${ }^{151}$

As far as enforcement is concerned, in the case of sovereign bonds, the creditor has always an unconditional claim against sovereign once the debtor State defaults under the bond instrument. Some authors therefore argue that as this claim against sovereign

is based on an unconditional promise to pay in the debt instrument and is normally capable of objective determination (did the sovereign pay or not?), there is little advantage to the lenders in adding to the claim against the sovereign for breach of the contractual payment obligation any additional claims against the same respondent for breach of international law obligations set out in an investment treaty. ${ }^{152}$

The same author adds that since the sovereign immunity from execution remains applicable, the advantage of better enforcement of investment awards might be more apparent than real. ${ }^{153}$

Domestic litigation practice over sovereign debt shows that the current enforcement mechanisms leave the debtor State in a much stronger position. ${ }^{154}$ The enforcement argument is based partially on the empirical observation that investment awards, ICSID awards in particular, enjoy a high level of voluntary compliance. ${ }^{155}$ Still, ICSID Awards should only be enforced in the Member States as final judgments of the domestic courts. Nevertheless, the case of Argentina shows that the results are not that straightforward. This conclusion calls for further qualification, as both ICSID Convention and New York Convention leave still considerable space for refusing enforcement or for nonexecution. ${ }^{156}$ The general lack of attachable assets abroad further qualifies the enforcement advantage. Moreover, as of the time of writing, ${ }^{157}$ investment arbitration has recorded only three decisions on the subject pending the determination of merits. How the matter will be addressed on the merits remains to be seen, as well as how the perceived enforcement advantages will prove to be effective in collecting the awards. Be that as it may, what is viewed to be yet another contribution of investment arbitration into the context of sovereign defaults is the use of the method or the resulting award as a bargaining chip. ${ }^{158}$ Incorporation of ICSID into the World Bank group further reinforces the bargaining leverage in favour of compliance with ICSID awards. ${ }^{159}$

150 Wälde, supra nt 9, 404; Waibel, supra nt 2, 316-318; Halverson Cross, supra nt 33. Another view holds that unavailability of investment arbitration for sovereign debt restructuring is unlikely to have negative effects on investors' confidence and States' ability to borrow on international financial markets: UNCTAD, Sovereign Debt Restructuring, supra nt 34, 8.

151 Waibel, supra nt 2, 316-317.

152 Kantor, M, "Are/should sovereign loans/debt be covered by BITs?", 2(1) Transnational Dispute Management (2005).

153 Ibid.

154 Szodruch, supra nt 36, 148.

155 Hatchondo et al, supra nt 14, 184; Waibel, supra nt, 2, 211.

156 Article 55, Convention on the Settlement of Investment Disputes between States and Nationals of Other States (1965) 4 ILM 524, (ICSID Convention); Article V, United Nations, Convention on the Recognition and Enforcement of Foreign Arbitral Awards (1958) 330 UNTS 3 (New York Convention).

157 (10 March 2015).

158 Wälde, supra nt 9, 421; Waibel supra nt 2, 212.

159 Halverson Cross, supra nt 33, 341. 


\section{IV.1.2. Disadvantages - Nationality, Predictability, Ad Hocism and Lack of Preventive Tools}

It is submitted here that under the current state of law, the cons of investment arbitration in sovereign bonds area outweigh the advantages.

A State's BITs coverage is limited and, as a result, investment claims can be pursued only by the nationals of the other contracting parties. Nationality of bondholders is by no means limited to the pool of nationals protected under the host States' BITs. Taking into account the pace at which the bond security entitlements can be traded on the secondary market, there seems to be no strong rationale as to the granting of IIA-covered holders priority over nationals not protected by the BITs. This would run counter to the wellestablished principle of equal treatment of creditors in debt restructuring. ${ }^{160}$

Coverage of investment treaties for sovereign debts is incidental to the nationality of bondholders. This has two consequences: it creates arbitrary inequality between different bondholders and it encourages abusive treaty shopping. ${ }^{161}$ If investment arbitration proves to be a more efficient means of holdout litigation, then certain bondholders holding exactly the same bond instruments of the same issue, as others will effectively own bonds with higher legal protection. This should have impact on the price of the bonds on the financial market. Nevertheless, the incidence of bondholders' nationality cannot be anyhow controlled by the debtor State at the time of the issue. Additionally, bondholders of the host State's nationality and the entire group of official creditors will be excluded. ${ }^{162}$ The conclusion reached here is that this creates legal uncertainty for the debtor State and undermines the contractual bargain agreed on the issuance. Additionally, the intervention of investment tribunals risk upsetting contractual equilibrium achieved during the bond issuance, and thus has further negative repercussions in the financial markets. ${ }^{163}$

Moreover, as was shown in the part dealing with security entitlements as investment under ICSID, it is argued that bonds can rather qualify as an investment on the issuance but the same cannot be said about the secondary market purchases, although Abaclat, Ambiente and Alemanni have decided otherwise. Should future tribunals follow the dissenters, this can create discrimination between institutional creditors, ie bond underwriters, and retail bondholders buying the security entitlements on the secondary market. It is submitted that such differential treatment can be justified as the two are not in the same position and have different roles in the bond issuance process.

The second area of concern is that current regime of investment arbitration operates on an ad hoc basis, even under the aegis of the World Bank in the case of ICSID. This feature can further decrease predictability of the outcomes. ${ }^{164}$ Should the investment arbitration be institutionalised in a standing body or equipped with some sort of standing appellate mechanism (the idea politically unfeasible), the predictability necessary in case of sovereign defaults would be secured to a larger extent. Certainty and predictability are important for functioning international capital markets and both regimes on foreign investments and sovereign defaults should take full account of it. As stated before,

\footnotetext{
160 Szodruch, supra nt 36, 150.

161 Reinisch, A, "State Insolvency - Consequences and Obligations under Investment Treaties Comment" in Hoffmann, R and Tams, CJ, eds, The International Convention for the Settlement of Investment Disputes (ICSID): Taking Stock after 40 Years (Nomos Publishers, Baden-Baden, 2007) 175-176.

$162 I d, 177$.

163 Waibel, supra nt 2, 316.

164 Reinisch, supra nt 161, 177.
} 
investment arbitration can deal only with the issue of holdouts. Therefore, certain linkage and institutional cooperation with other actors in the sovereign default field, ie with multilateral institutions such as IMF, IBRD, official lenders and other private players, would be necessary to address other issues (distressed financing, stay of proceedings, priority of creditors and the like). As the institutional background of ad hoc investment tribunals is weak, it is very probable that costs and complexity of restructuring, taking place in still largely a political realm, would be increased. ${ }^{165}$ This leads to the last drawback of the regime noted here, namely the lack of preventive tools.

Investment arbitration is a mechanism oriented exclusively to the past, ie to correct and remedy past grievances. The international system for solving sovereign debt crises should primarily be concerned with the tools for preventing sovereign defaults. Even if sufficiently grounded in a firm institutional framework and after elimination of arbitrary distinctions based on nationality, investment arbitration should be used merely as one of the tools available for dealing with sovereign debt disputes. Investment arbitration is by no means a panacea for States' debt crises. ${ }^{166}$

Some authors even point out that the purposes of BITs and sovereign insolvency regime, whatever its current informal state, do not match and even seem to run against each other. BITs are directed primarily to protection of foreign investment in order to balance the State's regulatory power and political risk, whereas sovereign insolvency regimes go in the direction of protecting the State from its creditors. As the State cannot be liquidated, the creditors are required to suffer certain haircuts in order to keep a balance towards the State's functions and the welfare of its citizens. ${ }^{167}$ As ICSID has a selective jurisdiction as far as nationality is concerned and also excludes certain types of creditors, it cannot serve as a general forum for State insolvency. Mechanisms such as SDRM require jurisdiction over all the debtor State's creditors whereby guaranteeing equal treatment of them. ${ }^{168}$

Finally, should States prefer to exclude hearing of sovereign bond disputes under ICSID, they have a readily available option to exempt certain types of dispute from ICSID coverage by a declaration under Article 25(4). So far no State has used the option. ${ }^{169}$

\section{Conclusion}

The article highlighted the main areas of concern when investment arbitration is used as a dispute settlement method for solving sovereign default differences. It has been demonstrated that the field of State insolvency is an area where a wider set of tools is necessary to address complex issues arising therefrom. The view advocated here was that

165 Waibel, supra nt, 2, 318.

166 The inappropriateness of adjudication for dealing with sovereign debt crises has been pointed out by Lee Buccheit. Buchheit, supra nt 4.

167 Gnam, P, "State Insolvency - Consequences and Obligations under Investment Treaties, Comment" in Hoffmann, R and Tams, CJ, eds, The International Convention for the Settlement of Investment Disputes (ICSID): Taking Stock after 40 Years (Nomos Publishers, Baden-Baden, 2007), 169-170.

168 Reinisch, supra nt 161, 177.

169 International Centre for the Settlement of Investment Disputes, REPORT: Notifications Concerning Classes of Disputes Considered Suitable or Unsuitable for Submission to the Centre, in Contracting States and Measures Taken by Them for the Purposes of the Convention, July 2012, at $<$ icsid.worldbank.org/apps/ICSIDWEB/icsiddocs/Documents/ICSID\%208\%20-\%201atest\%20\%20Nov\%2010\%202014.pdf> (accessed 9 April 2015). 
investment arbitration can at best serve as one of the forums available for holdout litigation.

In the area of international financial law there is clearly a lack of formal regimes for State insolvency. Even though attempts have been made, they were subsequently rejected. Any further attempt to introduce arguably a bold global institutional framework based on a multilateral treaty is not likely to be successful in the near future. This is partly due to the fact that the current, to a large extent contractual, approach connected with consensual negotiated debt restructuring in case of a default, has not proven to be unsustainable or unworkable. Such problems as an international stay of enforcement pending restructuring, lack of priority rules or provision for emergency private distressed financing remain unresolved.

Two aspects of sovereign risk in international regimes on sovereign defaults have not been entirely addressed by the current devices - the issue of sovereign immunity from execution and connected enforcement problems and the issue of lack of bankruptcy-like features in the international realm. It has been argued that investment arbitration as another avenue for holdout adjudication may partly alleviate the former aspect. It has been argued that should this forum be favourable to creditors without concurrent adjustments towards formal bankruptcy features, the balance between creditors' and debtors' rights can swing towards a higher protection of the former and thus impede future orderly restructuring. Holdout litigations based on pari passu clauses have proved, however, that they can lead to highly discomforting results, and even throw a restructuring country back to a default. Reasonable debt workouts should take full account of State's good faith efforts to remedy the situation and its real economic and financial capabilities in order to be held to its debt obligations. Investment arbitration is an ad hoc mechanism dealing with isolated claims adjudicating past grievances allegedly committed against the claimants. It cannot be expected that such a mechanism could be properly equipped to see and address a complex picture of intertwined economic and financial realities involved in sovereign defaults.

It has also been argued throughout the article that the legal basis for upholding jurisdiction over sovereign bonds under applicable international treaties is not free from objections. Under the current state of law, the problem of nationality requirements under IIAs creates unjustified discrimination between various bondholders and from a policy perspective is not tenable.

Professor Abi-Saab in his dissenting opinion called for caution when admitting jurisdiction in investment arbitration cases and warned from ever-extending jurisdiction of investment tribunals. This can induce a backlash against the system that might be already visible. However, if sovereign debt instruments will prove to be another field occupied by investment arbitration, States might need to be more cautious when they offer solutions in a debt restructuring process to their creditors. Attempts to use investment arbitration are not peculiar to the Argentine crisis, but are more pressing with the current Eurozone crisis of Greek debt restructuring. ${ }^{170}$ Investment arbitration should, nevertheless, be used for sovereign debt disputes only in conjunction with appropriate

170 See Karadelis, K, "Greece: a new Argentina?", 7(4) Global Arbitration Review (2012) at <globalarbitrationreview.com/journal/article/30603/Greece-new-argentina/> (accessed 9 April 2015); Network for Justice in Global Investment, Stirk, D, Proposed Greek Collective Action Clauses Law May Trigger Its International Law Obligations, at <justinvestment.org/2012/02/proposed-greek-collectiveaction-clauses-law-may-trigger-its-international-law-obligations/> (accessed 9 May 2015); Glinavos, supra nt 68. 
institutional adjustments in the field of both investment law and international insolvency regimes.

In the long run, the availability of treaty arbitration in area of debt restructuring could help this procedure to reach a mutually beneficial result to a larger extent for the State and the creditors. The interest of both sides must be taken in to account. Investment arbitration should not serve as an obstacle by the use of which a minority of creditors might block a majority consensual restructuring. 